\title{
Impaired $\beta$-cell function in the adult offspring of rats fed a protein-restricted diet during lactation is associated with changes in muscarinic acetylcholine receptor subtypes
}

\author{
Júlio C. de Oliveira ${ }^{1} \dagger$, Rosiane A. Miranda ${ }^{1} \dagger$, Luiz F. Barella ${ }^{1}$, Rosana Torrezan ${ }^{2}$, Aryane R. Agostinho ${ }^{1}$, \\ Tatiane A. S. Ribeiro ${ }^{1}$, Claudinéia C. S. Franco ${ }^{1}$, Ananda Malta ${ }^{1}$, Laize P. Tófolo ${ }^{1}$, Clarice Gravena ${ }^{1}$ \\ and Paulo C. F. Mathias ${ }^{1 *}$ \\ ${ }^{1}$ Laboratory of Secretion Cell Biology, Department of Cell Biology and Genetics, Block H67, Room 19, State University of \\ Maringá/UEM, Colombo Avenue 5790, 87020-900 Maringá, PR, Brazil \\ ${ }^{2}$ Department of Physiological Sciences, State University of Maringá, Maringá, PR, Brazil
}

(Submitted 18 October 2012 - Final revision received 4 June 2013 - Accepted 6 June 2013 - First published online 11 July 2013)

\begin{abstract}
Impaired pancreatic $\beta$-cell function, as observed in the cases of early nutrition disturbance, is a major hallmark of metabolic diseases arising in adulthood. In the present study, we aimed to investigate the function/composition of the muscarinic acetylcholine receptor (mAChR) subtypes, $\mathrm{M}_{2}$ and $\mathrm{M}_{3}$, in the pancreatic islets of adult offspring of rats that were protein malnourished during lactation. Neonates were nursed by mothers that were fed either a low-protein (4\%, LP) or a normal-protein $(23 \%, \mathrm{NP})$ diet. Adult rats were pre-treated with anti-muscarinic drugs and subjected to the glucose tolerance test; the function and protein expression levels of $\mathrm{M}_{2} \mathrm{mAChR}$ and $\mathrm{M}_{3} \mathrm{mAChR}$ were determined. The LP rats were lean and hypoinsulinaemic. The selective $\mathrm{M}_{2} \mathrm{mAChR}$ antagonist methoctramine increased insulinaemia by $31 \%$ in the NP rats and $155 \%$ in the LP rats, and insulin secretion was increased by $32 \%$ in the islets of the NP rats and $88 \%$ in those of the LP rats. The selective $\mathrm{M}_{3} \mathrm{mAChR}$ antagonist 4-diphenylacetoxy- $N$-methylpiperidine methiodide decreased insulinaemia by $63 \%$ in the NP rats and $40 \%$ in the LP rats and reduced insulin release by $41 \%$ in the islets of the NP rats and $28 \%$ in those of the LP rats. The protein expression levels of $\mathrm{M}_{2} \mathrm{mAChR}$ and $\mathrm{M}_{3} \mathrm{mAChR}$ were $57 \%$ higher and $53 \%$ lower, respectively, in the islets of the LP rats than in those of the NP rats. The expression and functional compositions of $\mathrm{M}_{2} \mathrm{mAChR}$ and $\mathrm{M}_{3} \mathrm{mAChR}$ were altered in the islets of the LP rats, as a result of metabolic programming caused by the protein-restricted diet, which might be another possible effect involved in the weak insulin secretion ability of the islets of the programmed adult rats.
\end{abstract}

Key words: Lean phenotype: Muscarinic receptor subtypes: Insulin secretion: Pancreatic islets

It has been suggested by a substantial number of epidemiological and experimental studies that the origin of several health problems in later life that are associated with the metabolic syndrome, such as obesity, hypertension, heart diseases and type 2 diabetes mellitus, is attributed to insults during fetal and neonatal life ${ }^{(1-6)}$. Although the proliferation of pancreatic islet cells increases just before birth and during the neonatal period, including the lactation period, it has been observed that the amount of DNA in the islet tissue of pups increases ${ }^{(7)}$. During the early developmental period of life, individuals are highly susceptible to adverse environmental conditions, such as a poor-protein diet, which may disrupt pancreatic $\beta$-cell function $^{(8)}$. If maternal undernourishment occurs either during gestation or in early postnatal life, it leads to functional changes in insulin secretion and glucose metabolism ${ }^{(9-12)}$.

It is known that energy/protein restriction during either gestation or gestation and lactation induces a profile of metabolic changes ${ }^{(12,13)}$ that is different from that observed for protein deprivation during lactation alone ${ }^{(12,14)}$. The former type of diet restriction generally causes high insulinaemia associated with insulin resistance in adult offspring, whereas the latter leads to low insulinaemia associated with high insulin sensitivity. Plasma insulin levels and insulin sensitivities in rat offspring that are metabolically programmed by an early

\footnotetext{
Abbreviations: 4-DAMP, 4-diphenylacetoxy- $N$-methylpiperidine methiodide; ACh, acetylcholine; ANS, autonomous nervous system; Atr, atropine; BW, body weight; $\mathrm{mAChR}$, muscarinic acetylcholine receptors; $\mathrm{M}_{1} \mathrm{mAChR}$, muscarinic acetylcholine receptor subtype $\mathrm{M}_{1}$; $\mathrm{M}_{3} \mathrm{mAChR}$, muscarinic acetylcholine receptor subtype $\mathrm{M}_{3}$; MTT, methoctramine; NP, normal-protein group; LP, low-protein group.
}

*Corresponding author: P. C. F. Mathias, fax +55443011 4892, email pmathias@uem.br

† Both authors contributed equally to this work. 
protein restriction diet depend on the time the rat dams started consuming the diet ${ }^{(15)}$.

The autonomous nervous system (ANS) is an important regulator of metabolic homeostasis ${ }^{(16,17)}$. The involvement of the ANS in the impaired function of pancreatic $\beta$-cells has been demonstrated in adult rats that experienced maternal protein malnourishment ${ }^{(18,19)}$. It is important to highlight that chronic protein malnourishment induces ANS imbalance, which is associated with pancreatic islet dysfunction ${ }^{(20)}$. Our laboratory has reported previously that maternal protein restriction leads to changes in the ANS activity of offspring rats $^{(19)}$, in particular, a low parasympathetic tone without noticeable changes in the sympathetic tone ${ }^{(18)}$.

Increased parasympathetic activity potentiates glucosestimulated insulin secretion in pancreatic $\beta$-cells ${ }^{(17,21)}$ through acetylcholine $(\mathrm{ACh})$ released by the pancreatic vagus neural ends ${ }^{(22)}$. The binding of ACh to the muscarinic acetylcholine receptors ( $\mathrm{mAChR}$ ) on the $\beta$-cell surface leads to an insulinotropic effect; this effect is associated specifically with the binding of $\mathrm{ACh}$ to the $\mathrm{M}_{3} \mathrm{mAChR}$ subtype $\left(\mathrm{M}_{3} \mathrm{mAChR}\right)$ and, to a lesser extent, to the $M_{1} m A C h R$ subtype $\left(M_{1} m A C h R\right)$. Although the insulinotropic effects of the $M_{1}$ and $M_{3}$ subtypes are best described, the other mAChR subfamilies (the $\mathrm{M}_{2} \mathrm{mAChR}$ subtype and, to a lesser extent, the $\mathrm{M}_{4} \mathrm{mAChR}$ subtype) block ACh insulinotropic action upon ACh binding. These contradictory and direct physiological effects of ACh on insulin secretion are exclusively mediated by mAChR.

ACh signal transduction in $\beta$-cells is mediated by $G$ proteins. When ACh binds to the $\beta$-cell membrane's $\mathrm{M}_{2} \mathrm{mAChR}$ or $M_{4} \mathrm{mAChR}$, it attenuates insulin secretion through the inhibitory action of the adenylate cyclase through $G_{i}$ protein. On the other hand, upon the binding of $A C h$ to $M_{1} m A C h R$ or $\mathrm{M}_{3} \mathrm{mAChR}$, it amplifies insulin secretion through $\mathrm{G}_{\mathrm{s}}$ protein by the activation of phospholipase $\mathrm{C}$, which increases inositol 1,4,5-trisphosphate and diacylglycerol levels ${ }^{(17)}$.

Plasma insulin levels fluctuate because of the presence of several factors that can stimulate, potentiate and/or inhibit pancreatic $\beta$-cells at the same time. Beyond the cephalic phase of insulin secretion, it has been shown that during food intake and in the postprandial phase, blood insulin concentration oscillates as $\beta$-cell function increases or decreases ${ }^{(16,17,23)}$. It seems reasonable that the cholinergic response in pancreatic $\beta$-cells could be a result of the amount and/or activity of different mAChR subfamilies. Recently, it has been demonstrated that the lack of $\mathrm{M}_{3} \mathrm{mAChR}$ in pancreatic $\beta$-cells is responsible for the lean and hypoinsulinaemic phenotype in some mice ${ }^{(24)}$, which is similar to the phenotype observed in early undernourished rats. Thus, the present study was designed to understand the role of pancreatic $\beta$-cell $\mathrm{mAChR}$ function in the disruption of glucose homeostasis and poor insulin release in early undernourished rats.

Although it is known that maternal malnutrition during lactation leads to the impairment of pancreatic $\beta$-cell function and the consequent inability to secrete insulin, it is unclear which molecular mechanisms are involved in the reduced insulin secretion in this experimental model of metabolic programming.

\section{Experimental methods}

\section{Dietary manipulation of lactating rats}

Female Wistar rats were fed a normal laboratory diet with $23 \%$ $(\mathrm{w} / \mathrm{w})$ protein content $\left(\mathrm{Nuvital}^{\circledR}\right)$ throughout pregnancy. After birth, the rats were distributed into two groups, and each lactating dam (eight litters for each experimental group) was housed with six pups (preferentially male). However, when the required number of male offspring in the litter was not reached, female newborns were used to adjust the litter size to six pups throughout the suckling phase. Because of sex differences in insulin levels and glucose tolerance as has been observed in some studies of early protein-restricted feeding ${ }^{(25)}$, after weaning, only male offspring were used in the experiments. In the normal-protein (NP) group, all dams were fed a normal-protein (23\%) diet ad libitum during lactation, whereas the low-protein (LP) group were fed a $4 \%(\mathrm{w} / \mathrm{w})$ protein diet with the same amount of energy as the normal diet, as described previously ${ }^{(18,26)}$. In the LP group, all dams were fed a low-protein diet ad libitum during the first $14 \mathrm{~d}$ of lactation and a normal diet for the third phase of the lactation period. At the age of $21 \mathrm{~d}$, the pups were weaned and thereafter fed a normal diet up to the age of $90 \mathrm{~d}$, the period when the rats were analysed. Throughout the experimental period, the rats were kept under controlled conditions of temperature $\left(22 \pm 2^{\circ} \mathrm{C}\right)$ and light (07.00-19.00 hours), with ad libitum access to water and food.

The Ethical Committee for the Animal Experiments of the State University of Maringá, which adheres to the Brazilian Federal Law, approved the protocol.

\section{Intravenous glucose tolerance test and the effects of muscarinic antagonists}

Under ketamine and xylazine anaesthesia $(3$ and $0.6 \mathrm{mg} / 100 \mathrm{~g}$ body weight (BW), respectively), a silicone cannula was implanted into the right jugular vein of each rat from both groups and stabilised in the dorsal region of the neck. The cannula was treated previously with heparinised saline (50 IU heparin/ml (0.83 nkat/l) of saline solution $(\mathrm{NaCl}$ $0.9 \%, \mathrm{w} / \mathrm{v}))$ to avoid the clotting of blood. After a $12 \mathrm{~h}$ fast (19.00-07.00 hours) and without anaesthesia, a glucose load ( $1 \mathrm{~g} / \mathrm{kg} \mathrm{BW}$ ) was infused, through the cannula, into the bloodstream of sixteen to eighteen rats in both groups. Blood samples (350-400 $\mu \mathrm{l})$ were collected immediately before the infusion of the glucose load $(0 \mathrm{~min})$ and at 5, 15, 30 and $45 \mathrm{~min}$.

To study the influence of muscarinic receptors on glycaemic changes, $5 \mathrm{~min}$ before the infusion of the glucose load, we used a physiological agonist, ACh ( $27 \mathrm{nmol} / \mathrm{l}$ per $\mathrm{kg} \mathrm{BW})$, or a non-selective antagonist, atropine (Atr, $20 \mathrm{nmol} / \mathrm{l}$ per $\mathrm{kg} \mathrm{BW}$ ), which was intraperitoneally injected into the other batch of rats from each group ( $n$ 12-16). To investigate whether the decreased insulin response to glucose as has been observed in this model is related, at least in part, to the increased or decreased function/sensitivity of $\mathrm{M}_{2} \mathrm{mAChR}$ or $\mathrm{M}_{3} \mathrm{mAChR}$, respectively, we studied the effects of a selective $M_{2} m A C h R$ 
antagonist (methoctramine (MTT) $2 \mu \mathrm{mol} / 1$ per $\mathrm{kg} \mathrm{BW}$ ) and a selective $\mathrm{M}_{3} \mathrm{mAChR}$ antagonist (4-diphenylacetoxy- $N$-methylpiperidine methiodide (4-DAMP) $0.21 \mu \mathrm{mol} / 1$ per $\mathrm{kg} \mathrm{BW}$ ) in different experimental groups (n 14-16). Blood samples were collected at the times indicated above, and plasma samples obtained were stored at $-20^{\circ} \mathrm{C}$ for further analyses. Glucose concentration was determined by the glucose oxidase method ${ }^{(27)}$ using a commercial kit (Gold Analisa ${ }^{\circledR}$ ). Insulin levels were determined using a RIA ${ }^{(28)}$ with a gamma counter (2470 Wizard ${ }^{2}$ Automatic Gamma Counter, PerkinElmer ${ }^{\circledR}$ ). The other reagents used were human insulin as a standard, an anti-rat insulin antibody (Sigma-Aldrich ${ }^{\circledR}$ ) and ${ }^{125}$ I-labelled recombinant human insulin (PerkinElmer ${ }^{\circledR}$ ).

The intra- and inter-assay CV were, respectively, $12 \cdot 2$ and $9 \cdot 8 \%$ for insulin. The detection limit for insulin levels was $1 \cdot 033 \mathrm{pmol} / 1$.

\section{Isolation of pancreatic islets}

Pancreatic islets were isolated using a collagenase technique as described previously ${ }^{(29)}$ with some adaptations. For this purpose, 90-d-old rats were decapitated, and the abdominal wall was opened. Into the rats' common bile duct, $8 \mathrm{ml}$ of Hank's buffered saline solution (composition in $\mathrm{mmol} / \mathrm{l}$ : $\mathrm{NaCl}, 136 \cdot 9 ; \mathrm{KCl}, 5 \cdot 4 ; \mathrm{MgSO}_{4} .7 \mathrm{H}_{2} \mathrm{O}, 0 \cdot 81 ; \mathrm{Na}_{2} \mathrm{HPO}_{4}, 0 \cdot 34 ;$ $\mathrm{KH}_{2} \mathrm{PO}_{4}, 0 \cdot 44 ; \mathrm{CaCl}_{2} \cdot 2 \mathrm{H}_{2} \mathrm{O}, 1 \cdot 26 ; \mathrm{NaHCO}_{3}, 4 \cdot 16 ;$ glucose, 0.06; bovine serum albumin 15; (v/v): 95\% $\mathrm{O}_{2}+5 \% \mathrm{CO}_{2}$, mixed/10 min, $\mathrm{pH} 7 \cdot 4)$ containing $0 \cdot 1 \%$ collagenase type XI plus $5 \%$ bovine serum albumin and $0.6 \%$ HEPES (w/v) (Sigma-Aldrich ${ }^{\circledR}$ ) were injected. The pancreas, swollen with the collagenase solution, was quickly excised and incubated at $37^{\circ} \mathrm{C}$ in a glass beaker for $17-18 \mathrm{~min}$ for the NP rats or 11-12 min for the LP rats. The suspension was then discarded, and the pancreas was washed with Hank's buffered saline solution in three continuous washings. The islets were collected with the aid of a stereomicroscope. At least three rats from three different litters were used for each experimental procedure in a group.

\section{Stimulation of insulin secretion}

To adapt the isolated islets to a baseline glucose concentration $(5.6 \mathrm{mmol} / \mathrm{l})$, the islets (four islets per well) were preincubated for $60 \mathrm{~min}$ in $1 \mathrm{ml}$ of normal Krebs-Ringer solution (composition in mmol/l: NaCl, 115; $\mathrm{NaHCO}_{3}, 24 ; \mathrm{KCl}, 1 \cdot 6$; $\mathrm{MgCl} .6 \mathrm{H}_{2} \mathrm{O}, 1 ; \mathrm{CaCl}_{2} .2 \mathrm{H}_{2} \mathrm{O}, 1$; bovine serum albumin, 15), $\mathrm{pH} 7 \cdot 4$, that contained $5.6 \mathrm{~mm}$-glucose. This solution was gassed with $95 \% \mathrm{O}_{2}$ mixed with $5 \% \mathrm{CO}_{2}$ to maintain a $\mathrm{pH}$ of $7 \cdot 4$. To study mAChR function, following pre-incubation, the islets were incubated for an additional $60 \mathrm{~min}$ in the Krebs-Ringer solution containing $8.3 \mathrm{~mm}$-glucose and/or $8.3 \mathrm{~mm}$-glucose plus $10 \mu \mathrm{M}$-ACh in the presence of neostigmine $(10 \mu \mathrm{mol} / \mathrm{l})$ to prevent the action of acetylcholinesterase in the islets. To block the $\mathrm{M}_{2} \mathrm{mAChR}$ and $\mathrm{M}_{3} \mathrm{mAChR}$ subtype functions, MTT $(1 \mu \mathrm{mol} / \mathrm{l})$ and 4-DAMP (100 $\mu \mathrm{mol} / \mathrm{l})$, respectively, were used.

All of the drugs described above for studying mAChR function were purchased from Sigma-Aldrich.

\section{Measurement of the fat pad stores}

On the completion of all the experimental procedures, the rats ( $n$ 30) were killed, and their fat pad stores (retroperitoneal, periepididymal, visceral and inguinal) were removed and weighed.

\section{Western blot analyses}

The protein content of $\mathrm{M}_{2} \mathrm{mAChR}$ and $\mathrm{M}_{3} \mathrm{mAChR}$ in pancreatic islets isolated from the 90-d-old rats were determined by immunoblotting. In each experimental group, 300 islets were frozen at $-80^{\circ} \mathrm{C}$ in Hank's buffered saline solution and subjected to posterior sonication (two times, $10 \mathrm{~s}$ pulses, using a Sonic Dismembrator Model 100; Fisher Scientific) in $300 \mu \mathrm{l}$ of lysis buffer (composition in mmol/l: HEPES, 50; $\mathrm{MgCl}_{2}, 1$; EDTA, 10; Triton X, 1\%; v/v) and finally centrifuged at $10000 \mathrm{rpm}$ for $5 \mathrm{~min}$ at $4^{\circ} \mathrm{C}$. The supernatant was collected, and $10 \mu \mathrm{l} / \mathrm{ml}$ of protease inhibitor cocktail (Roche ${ }^{\circledR}$ ) were added; the total protein content was determined by the $\mathrm{BCA}^{\mathrm{TM}}$ protein assay kit (Thermo Scientific ${ }^{\circledR}$ ) using a microplate reader (Multi-Mode Reader, FlexStation ${ }^{\circledR} 3$ Benchtop; Molecular Devices). The samples were treated with Laemmli sample buffer (w/v: glycerol, 20\%; $\beta$-mercaptoethanol, $10 \% ; 10 \%$ SDS, $40 \%$; $0.5 \mathrm{~m}$-Tris, at pH 6.8, 0.5\%; deionised water; bromophenol blue $)^{(30)}$ and heated in a boiling water-bath for $3 \mathrm{~min}$.

Total protein extracts $(40 \mu \mathrm{g})$ from the pancreatic islets were separated by $10 \%$ SDS-PAGE at $90 \mathrm{~V} / 120 \mathrm{~min}$. A standard molecular weight marker was loaded in parallel. Proteins were then transferred from the gel onto a nitrocellulose membrane using the Trans-Blot ${ }^{\circledR}$ Semi-Dry 15-minutes Electrophoretic Transfer Cell (Bio-Rad ${ }^{\circledR}$ ) and blocked with 5\% skimmed milk in Tween-Tris-buffered saline (Tris-HCl, $1 \mathrm{~mol} / \mathrm{l} ; \mathrm{NaCl}$, $5 \mathrm{~mol} / \mathrm{l}$; Tween-20, $0.05 \%, \mathrm{v} / \mathrm{v}$ ) at room temperature for 90 min with continuous shaking. Next, the membrane was incubated overnight at $4^{\circ} \mathrm{C}$ with rabbit anti- $\mathrm{M}_{2} \mathrm{mAChR}$ and anti- $\mathrm{M}_{3} \mathrm{mAChR}$ polyclonal primary antibodies at a 1:1000 dilution (Sigma-Aldrich ${ }^{\circledR}$ ), followed by incubation with a peroxidase-conjugated anti-rabbit antibody at a 1:5000 dilution (Sigma-Aldrich ${ }^{\circledR}$ ). The antibodies were diluted in a buffer with a composition of $20 \mathrm{~mm}$-Tris- $\mathrm{HCl}, 137 \mathrm{~mm}-\mathrm{NaCl}$ and $0.05 \%$ Tween 20 . The procedure was repeated three times using a different pool of 300 islets from two to four rats obtained from two different litters of each experimental group.

The immunoreactive proteins were visualised using an ECL kit (GE Healthcare) and a scanner device (Amersham Storm ${ }^{\mathrm{TM}}$ 860 Imaging System; Gene Tool). The bands were quantified by densitometry using the Image J 1.4 Software (Wayne Rasband National Institute of Health).

The expression of $\beta$-actin protein determined using an anti- $\beta$-actin polyclonal primary antibody (diluted 1:1000 in Tween-Tris-buffered saline; Santa $\mathrm{Cruz}^{\circledR}$ Biotechnology) was utilised for normalisation.

\section{Statistical analyses}

Data are presented as means with their standard errors, and they were subjected to Student's $t$ test or one-way ANOVA, followed by a Bonferroni $t$ test. $P<0.05$ was considered 
statistically significant. Tests were performed using GraphPad Prism version 5.0 for Windows (GraphPad Software, Inc.).

\section{Results}

\section{Metabolic programming profile}

As reported previously, the LP rats had a predominantly lean phenotype (lower retroperitoneal $(-29 \%, P<0 \cdot 001)$, periepididymal $(-26 \%, P<0.001)$, visceral $(-26 \%, P<0.001)$ and inguinal $(-27 \%, P<0.01)$ fat pad stores and lower body weight $(-17 \%, P<0.001)$ and length $(-6 \%, P<0.001)$; all values compared with those of the NP rats). The metabolically programmed LP rats are not only normoglycaemic but also hypoinsulinaemic - 56\% lower plasma insulin levels compared with those in the NP rats (Student's $t$ test: $P=0.052$ and $P<0 \cdot 001$; Table 1).

\section{Glucose homeostasis during the intravenous glucose tolerance test}

It is known that these programmed rats have high peripheral insulin sensitivity (data not shown), even though the rats exhibited both glucose intolerance $(+16.5 \%, \quad P<0.01)$ during the intravenous glucose tolerance test, as shown in the inset of Fig. 1(A), and low insulinaemia ( $-48.4 \%$, $P<0 \cdot 01)$, as shown in Fig. 1(B).

\section{Effect of muscarinic antagonists in vivo}

during the intravenous glucose tolerance test on glucose homeostasis

Fig. 2(A) shows the in vivo results of treatment with an agonist and an antagonist of the muscarinic receptors $(P<0.001)$. As expected, ACh treatment decreased the percentage of AUC glycaemic increment during the intravenous glucose tolerance test to $16 \%$ in the NP rats, whereas this increment was $37 \%$

Table 1. Effect of a protein-restricted diet during the first two of the three weeks of the lactation period on the biometric and biochemical parameters of adult rat offspring $\ddagger$

(Mean values with their standard errors, $n 30$ rats per group)

\begin{tabular}{|c|c|c|c|c|}
\hline \multirow{2}{*}{$\begin{array}{l}\text { Biometric and } \\
\text { biochemical parameters }\end{array}$} & \multicolumn{2}{|c|}{ NP } & \multicolumn{2}{|c|}{ LP } \\
\hline & Mean & SEM & Mean & SEM \\
\hline Body weight (g) & $376 \cdot 20$ & $4 \cdot 20$ & $311.00^{\star \star \star}$ & 2.90 \\
\hline Body length $(\mathrm{cm})$ & $22 \cdot 76$ & 0.07 & $21 \cdot 38^{\star \star \star}$ & 0.09 \\
\hline $\begin{array}{l}\text { Retroperitoneal fat } \\
(\mathrm{g} / 100 \mathrm{~g} \mathrm{BW})\end{array}$ & 1.02 & 0.04 & $0.72^{\star \star \star}$ & 0.03 \\
\hline $\begin{array}{l}\text { Periepididymal fat } \\
(\mathrm{g} / 100 \mathrm{~g} \mathrm{BW})\end{array}$ & 0.85 & 0.03 & $0 \cdot 63^{\star \star \star}$ & 0.01 \\
\hline Visceral fat ( $\mathrm{g} / 100 \mathrm{~g} \mathrm{BW})$ & 0.70 & 0.03 & $0.52^{\star \star \star}$ & 0.02 \\
\hline Inguinal fat (g/100 g BW) & 0.29 & 0.02 & $0.21^{\star \star}$ & 0.02 \\
\hline Fasting glucose (mmol/l) & 4.83 & 0.15 & $5 \cdot 28 \dagger$ & 0.17 \\
\hline Fasting insulin (pmol/l) & $29 \cdot 30$ & $2 \cdot 84$ & $17 \cdot 55^{\star * \star}$ & 2.63 \\
\hline
\end{tabular}

NP, normal protein; LP, low protein; BW, body weight.

Mean value was significantly different from that of the NP group: ${ }^{\star \star} P<0.01$, ${ }^{\star \star \star} P<0.001$ (Student's $t$ test).

† Mean value was not significantly different from that of the NP group $(P=0.052$ Student's $t$ test).

$\ddagger$ Adult rat offspring from eight distinct litters were studied. higher in the LP rats compared with the respective NP and LP AUC glycaemic values observed without treatment. Treatment with Atr, a non-selective muscarinic antagonist, led to an increase of $26 \%$ in the glycaemic values of the NP rats, whereas Atr had no effect on glycaemia in the LP rats. Pretreatment with MTT, a selective $\mathrm{M}_{2} \mathrm{mAChR}$ antagonist, decreased the AUC glycaemic values by $20 \%$ in the NP rats, whereas this decrease was $31 \%$ in the LP rats, compared with that in their respective controls without antagonist treatment. Pre-treatment with 4-DAMP, a selective $\mathrm{M}_{3} \mathrm{mAChR}$ antagonist, increased glycaemia by $16 \%$ in the NP rats, whereas in the LP rats, there was no change compared with the respective NP and LP glycaemic values observed without 4-DAMP pre-treatment.

While studying the in vivo muscarinic receptor functions, as shown in Fig. 2(B), it was observed that AUC insulinaemia was elevated by $55.5 \%$ in the NP rats by ACh pre-treatment $(P<0 \cdot 001)$, whereas there was no change in the LP rats. Insulinaemia was decreased by 30 and $22 \%$ in the NP and LP rats, respectively, when Atr treatment was administered $(P<0 \cdot 001)$. Although insulinaemia increased by $31 \%$ in the NP rats by MTT pre-treatment, it was $155 \%$ higher in the LP rats compared with that in their respective controls without MTT pre-treatment $(P<0 \cdot 001)$. 4-DAMP pre-treatment decreased AUC insulinaemia by 63 and $40 \%$ in the NP and LP rats, respectively, compared with that in their respective controls without drug pre-treatment $(P<0 \cdot 001 ;$ Fig. 2(B)).

\section{Effect of muscarinic antagonists in vitro on insulin secretion}

As shown in Fig. 3(A), the insulin secretion stimulated by $8.3 \mathrm{~mm}$-glucose in the islets of the LP rats was $2 \cdot 8$-fold lower than that in the islets of the NP rats $(171.76$ (SEM 14.46) pmol/1, NP; $61 \cdot 27$ (SEM 8.43) pmol/1, LP; one-way ANOVA).

To assess the in vitro insulinotropic effect of cholinergic agents on the insulin secretion stimulated by glucose, $10 \mu \mathrm{M}-$ ACh was used, which induced 3.5-fold less insulin secretion in the islets of the LP rats (106.70 (SEM 10.50) pmol/1) compared with that in the islets of the NP rats $(373.80$ (SEM 34.59) $\mathrm{pmol} / \mathrm{l}, P<0.001)$. The insulinotropic effect of MTT, a selective $\mathrm{M}_{2} \mathrm{mAChR}$ antagonist, resulted in a strong blockage of $\mathrm{M}_{2} \mathrm{mAChR}$ activity in both groups. MTT treatment led to 32 and $88 \%$ increases in insulin secretion in the islets of the NP and LP rats, respectively $(P<0 \cdot 001)$, as shown in Fig. 3(B). On the other hand, insulin secretion was blocked by 4-DAMP in the islets of both NP and LP rats. However, in the islets of the LP rats, 4-DAMP treatment decreased insulin secretion by 1.5 -fold compared with that in the islets of the NP rats. In addition, this inhibition was 41 and $28 \%$ in the islets of the NP and LP rats, respectively, compared with the insulin secretion induced by $8.3 \mathrm{~mm}$-glucose and $10 \mu \mathrm{m}$-ACh in the islets of both groups $(P<0.001$; Fig. 3(B)).

\section{Protein expression of muscarinic receptors in pancreatic islets}

As shown in Fig. 4(A), the protein expression of $\mathrm{M}_{2} \mathrm{mAChR}$ in the islets of the LP rats was increased by $57 \%$ compared with 
(A)

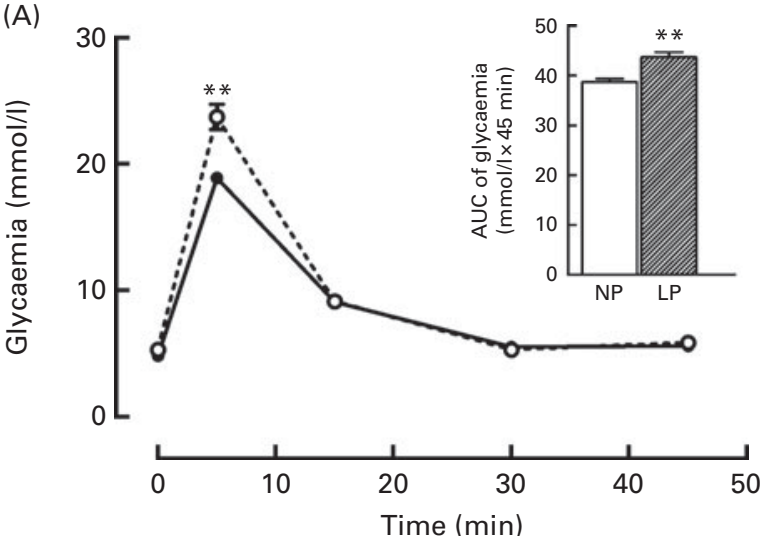

(B)

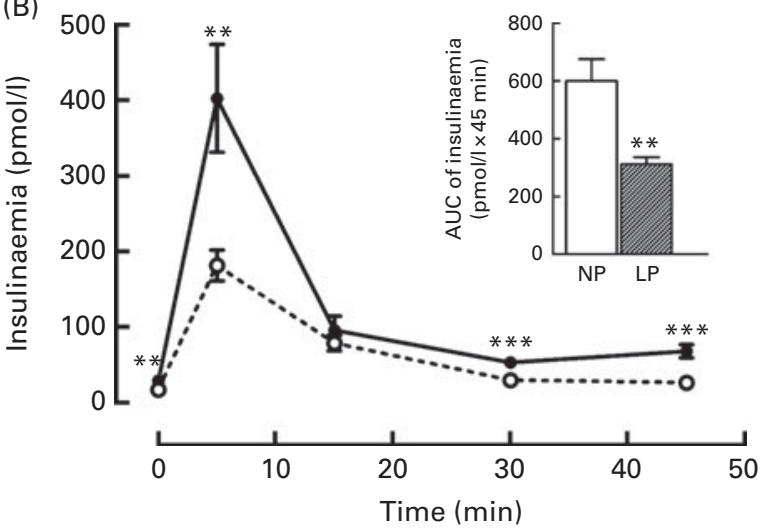

Fig. 1. Changes in the levels of plasma (A) glucose and (B) insulin during the intravenous glucose tolerance test (ivGTT). Values are means $(n 16-18$ rats per group), with their standard errors represented by vertical bars. (A, B) The inset represents the AUC of glycaemia and/or insulinaemia during the ivGTT, following pre-treatment with saline solution $(\mathrm{NaCl}, 0.9 \%)$. Mean value was significantly different from that of the NP group: ${ }^{* *} P<0.01,{ }^{* * *} P<0.001$ (Student's $t$ test). NP, normal-protein group (- $\rightarrow$ ); LP, low-protein group (•०).).

that in the NP rats; nevertheless, the protein levels of $\mathrm{M}_{3} \mathrm{mAChR}$ were reduced by $53 \%$ in the islets of the LP rats compared with those in the NP rats $(P<0 \cdot 01$; Fig. 4(B)).

\section{Discussion}

In the present study, we showed for the first time that the amounts of the major mAChR subtypes, $M_{3}$ and $M_{2}$, were altered in the pancreatic islets of rats that were programmed with a maternal low-protein diet. Although it is known that $\mathrm{M}_{3} \mathrm{mAChR}$ is the major functional receptor subtype that is expressed and responsible for the cholinergic insulinotropic effect in pancreatic islets/ $\beta$-cells ${ }^{(16,17,31)}$, the ratio of $\mathrm{M}_{2}: \mathrm{M}_{3}$ has not been reported previously. Upon activation, the even-numbered mAChR subtypes $\left(\mathrm{M}_{2}\right.$ and $\left.\mathrm{M}_{4}\right)$ in pancreatic $\beta$-cells block the insulinotropic effect of ACh. Similarly, the odd-numbered mAChR subtypes $\left(\mathrm{M}_{1}\right.$ and $\left.\mathrm{M}_{3}\right)$ in pancreatic $\beta$-cells block the action of $\mathrm{ACh}^{(17)}$. We found a 1.3-fold higher protein expression of $\mathrm{M}_{2} \mathrm{mAChR}$ than of $\mathrm{M}_{3} \mathrm{mAChR}$ in pancreatic islets isolated from the normal rats; this ratio was 4.6-fold higher in the islets of the LP rats, suggesting a possible cause for the drastic dysfunction in the ACh-potentiated insulin secretion observed in the islets of the low-proteindiet-programmed rats.

In the present study, we report that the low-protein-dietprogrammed rats have a characteristic lean phenotype and exhibit a disturbed glucose homeostasis associated with a low insulin release. An important question with serious pathophysiological implications is whether the low cholinergic response in the islets of LP animals is a protective effect against the increased peripheral insulin sensitivity in this experimental model ${ }^{(18,32-34)}$.

The phenotype of high insulin sensitivity is important for the development of obesity and type 2 diabetes later in life. Once changes in peripheral tissues, such as the up-regulation of the expression of insulin receptors in the skeletal muscle ${ }^{(32)}$ and the high expression of GLUT-4 in the white adipose

(A)

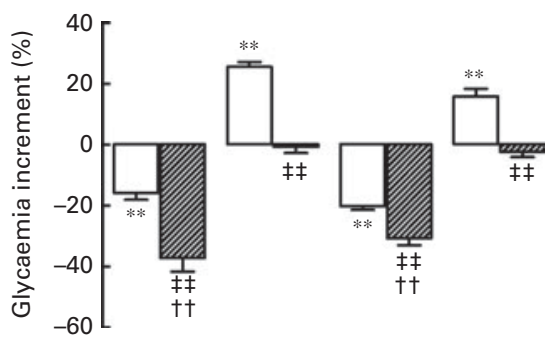

Glu $1 \mathrm{~g} / \mathrm{kg} \mathrm{BW}$

ACh $27 \mathrm{nmol} / \mathrm{l}$ per $\mathrm{kg}$ BW

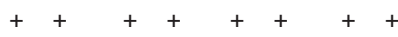

Atr $20 \mathrm{nmol} / \mathrm{l}$ per kg BW

MTT $2 \mu \mathrm{mol} / \mathrm{l}$ per kg BW

4-DAMP $0.21 \mu \mathrm{mol} / \mathrm{l}$ per $\mathrm{kg} \mathrm{BW} \mathrm{-} \mathrm{-}$

(B)

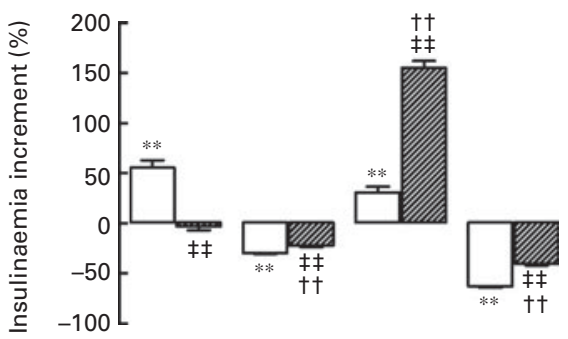

Glu $1 \mathrm{~g} / \mathrm{kg}$ BW

ACh $27 \mathrm{nmol} / \mathrm{l}$ per $\mathrm{kg} \mathrm{BW}$

Atr $20 \mathrm{nmol} / \mathrm{l}$ per kg BW

MTT $2 \mu \mathrm{mol} / \mathrm{l}$ per kg BW

4-DAMP $0.21 \mu \mathrm{mol} / \mathrm{l}$ per $\mathrm{kg} \mathrm{BW}$

$$
\begin{array}{cccccccc}
+ & + & + & + & + & + & + & + \\
+ & + & - & - & - & - & - & - \\
- & - & + & + & - & - & - & - \\
- & - & - & - & + & + & - & -
\end{array}
$$

Fig. 2. In vivo effect of pre-treatment with muscarinic receptor agonist and antagonist on (A) glycaemia and (B) insulinaemia during the intravenous glucose tolerance test (ivGTT). The line from 0 represents the total plasma AUC of (A) glycaemia and (B) insulinaemia throughout the ivGTT $(100 \%)$ induced by the glucose load in the normal-protein (NP, $\square$ ) or low-protein (LP, $\mathbf{m})$ rats without any drug pre-treatment. Values are mean percentages ( $n$ 12-16 rats per group), with standard errors represented by vertical bars. ${ }^{\star \star}$ Mean value was significantly different from that of the LP group $(P<0.01$; ANOVA). $\dagger †$ Mean value was significantly different from that of the NP group $(P<0.01$;

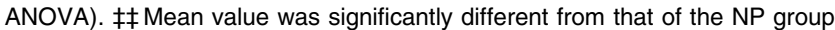
for each respective treatment $(P<0.01$; ANOVA). Glu, glucose; BW, body weight; ACh, acetylcholine; Atr, atropine; MTT, methoctramine; 4-DAMP, 4-diphenylacetoxy- $N$-methylpiperidine methiodide. 
(A)
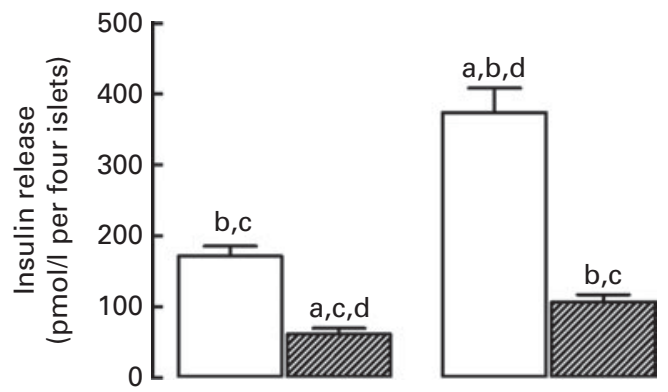

Glu $8.3 \mathrm{mmol} / \mathrm{l}$ ACh $10 \mu \mathrm{mol} / \mathrm{l}$

(B)
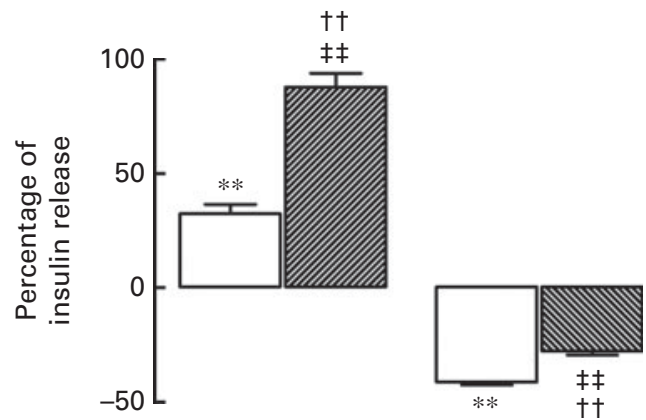

MTT $1 \mathrm{mmol} / \mathrm{l}$

4-DAMP $100 \mu \mathrm{mol} / \mathrm{I}$

Fig. 3. In vitro effect of muscarinic receptor agonist and antagonist on glucose (Glu)-induced insulin secretion. (A) Insulin secretion was stimulated by $8.3 \mathrm{~mm}$-Glu and potentiated by $10 \mu \mathrm{M}$-acetylcholine (ACh). Values are means of twelve animals obtained from four different litters, with their standard errors represented by vertical bars. ${ }^{a, b, c, d}$ Mean values were significantly different between the normal-protein (NP, $\square$ ) and low-protein (LP, $(P<0.01$; one-way ANOVA): a, NP, Glu; b, LP, Glu; c, NP, ACh; d, LP, ACh. (B) Percentage of Glu-induced insulin secretion that is potentiated by $10 \mu \mathrm{M}$-ACh with either $1 \mu \mathrm{M}$-methoctramine (muscarinic acetylcholine receptor (mAChR) subtypes, $\mathrm{M}_{2}\left(\mathrm{M}_{2} \mathrm{mAChR}\right)$ antagonist) or $100 \mu \mathrm{M}$-4-diphenylacetoxy- $N$-methylpiperidine methiodide (muscarinic acetylcholine receptor (mAChR) subtypes, $M_{3}\left(M_{3} m A C h R\right)$ antagonist). The line from 0 represents the Glu-induced insulin secretion that is potentiated by $10 \mu \mathrm{M}$-ACh during $60 \mathrm{~min}$ of incubation $(100 \%)$ without any muscarinic antagonists in the islets of the NP or LP rats. Values are mean percentages, with their standard errors represented by vertical bars. ${ }^{* \star}$ Mean value was significantly different from that of the LP group $(P<0.01$; one-way ANOVA). †† Mean value was significantly different from that of the NP group $(P<0.01$; one-way ANOVA). $\ddagger \ddagger$ Mean value was significantly different from that of the NP group for each respective treatment $(P<0.01$; one-way ANOVA). 4-DAMP, 4-diphenylacetoxy- $N$-methylpiperidine methiodide.

tissue $^{(33)}$, have occurred in rats that are protein restricted during lactation, they adapt well to store energy reserves from an energy-rich diet and survive periods of food scarcity. The result of this adaptation is obesity because of the lipogenic effect of insulin when food is abundant ${ }^{(35)}$. Another consequence of this adaptation is $\beta$-cell exhaustion ${ }^{(36)}$, which occurs when there is a high insulin demand because of the peripheral insulin resistance associated with obesity.

Unfortunately, the mechanism by which $\beta$-cells of the LP islets secrete less insulin when stimulated by glucose is not yet determined. However, it has been suggested that the persistent activation of $\mathrm{M}_{3} \mathrm{mAChR}$ in $\beta$-cells could be a mechanism that explains the increased glucose-induced insulin release in obese animals ${ }^{(37)}$. Transgenic mice that express

the Q490L mutant of $\mathrm{M}_{3} \mathrm{mAChR}$ in $\beta$-cells are resistant to the impairment of glucose homeostasis when fed a high-fat diet. The islets isolated from these mutant mice, when stimulated by glucose, secrete more insulin than those isolated from wild-type littermates. This effect is cholinergic ligand independent ${ }^{(38)}$, indicating that the high glucose insulinotropic effect is associated with a high activity of $\mathrm{M}_{3} \mathrm{mAChR}$. It has been shown that the overexpression of $\mathrm{M}_{3} \mathrm{mAChR}$ in $\beta$-cells causes increased plasma insulin levels in the fasting and fed states of mutant mice ${ }^{(37)}$. Thus, it is reasonable to speculate that the low protein expression and/or low function of $\mathrm{M}_{3} \mathrm{mAChR}$ in pancreatic $\beta$-cells could lead to a low glucose insulinotropic effect. In the present study, adult rats that were protein restricted during lactation displayed both fastingand fed-state hypoinsulinaemia, and islets isolated from them exhibited a weak glucose insulinotropic response, which was associated with the low protein expression and low ligand pharmacological activity of $\mathrm{M}_{3} \mathrm{mAChR}$ in the isolated islets.

These data might support the hypothesis that a low glucose response in pancreatic $\beta$-cells is a consequence of a low activation of their $\mathrm{M}_{3} \mathrm{mAChR}$. Whole-body $\mathrm{M}_{3} \mathrm{mAChR}$ knockout mice display low body masses and plasma insulin levels ${ }^{(39)}$, a phenotype similar to that of the adult rats that were programmed with an early low-protein diet in the present study. It is remarkable that the islets of mutant mice, either whole body or only $\beta$-cell $\mathrm{M}_{3} \mathrm{mAChR}$ knockout, exhibit low glucose-induced insulin secretion ${ }^{(37,40)}$; this is also similar to the islet dysfunction in LP animals, as has been observed in the present study.

(A)

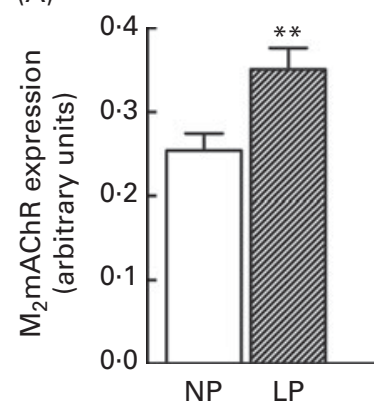

(B)

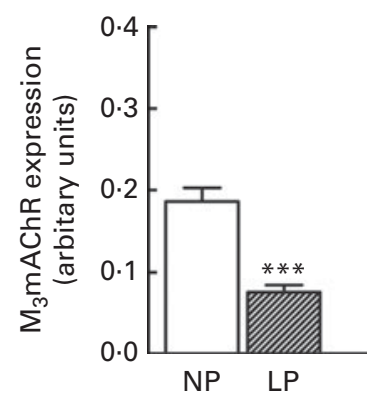

(C)
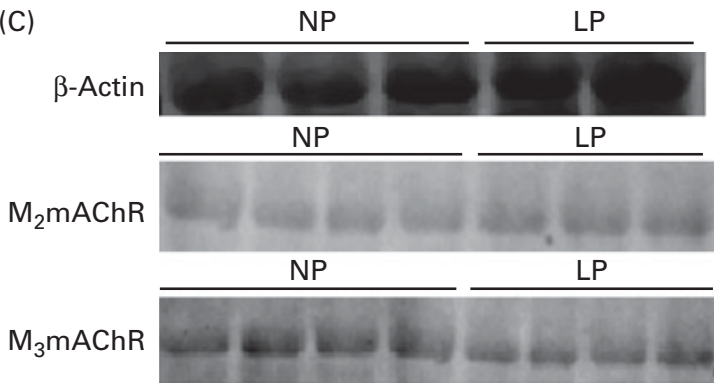

Fig. 4. Measurement of (A) $M_{2}$ and (B) $M_{3}$ muscarinic receptor protein levels in the pancreatic islets of adult rats. (C) Representative blots of $M_{2}$ and $M_{3}$ muscarinic receptor subtypes and $\beta$-actin (control load). Values are means of three different experiments, with three to four rats from two different litters in each group, with their standard errors represented by vertical bars. Mean value was significantly different from that of the NP group: ${ }^{* *} P<0.01$, ${ }^{* * *} P<0.001$ (Student's $t$ test). NP, normal-protein group; LP, low-protein group. 
Beyond the role of the low protein expression and function of the odd-numbered receptors, such as $\mathrm{M}_{3} \mathrm{mAChR}$ dysfunction in $\beta$-cells of the LP rats, there could be other contributing factors. For example, we did not study the insulinotropic effect of $\mathrm{M}_{1} \mathrm{mAChR}$. In addition, although we did not study the insulinostatic effect of $\mathrm{M}_{4} \mathrm{mAChR}$, we cannot ignore the role of even-numbered $\mathrm{mAChR}$ with increased function and protein expression, which could explain the low glucose-induced insulin secretion. In the islets of LP animals, the high protein expression and pharmacological activity of $\mathrm{M}_{2} \mathrm{mAChR}$ indicate that the cholinergic insulinotropic effect is attenuated by the action of a $\mathrm{M}_{2} \mathrm{mAChR}$ ligand. The $\beta$-cell $\mathrm{mAChR}$ results suggest that early protein restriction increases the ratio of $\mathrm{M}_{2}: \mathrm{M}_{3}$, resulting in adult offspring with glucose homeostasis disruption and $\beta$-cell dysfunction. The $\beta$-cells not only exhibit a reduced cholinergic insulinotropic response but also present a low glucose insulinotropic response. In fact, the low-protein-diet-programmed rats also displayed an unbalanced ANS function ${ }^{(18,19)}$, which could be responsible for the changes observed in $\beta$-cell mAChR in the present study.

As has been demonstrated previously, the offspring that were programmed by maternal protein malnourishment adapted to poor food supply ${ }^{(6,41)}$. Similar to humans who had experienced famine early in life ${ }^{(42,43)}$, the experimental model programmed by diet restriction during a critical developmental period $^{(44-46)}$ had a high risk of developing metabolic diseases, such as obesity and type 2 diabetes. The metabolic impairment is evident after weaning, when a high-energy diet results in imbalances in fat metabolism. In particular, the lowprotein-diet-programmed rats in the present study seemed to be unable to develop obesity in adulthood when fed a protein-restricted diet; the mechanism responsible for this observation is unclear. It might be due to the specific time of metabolic programming (i.e. metabolic programming by a maternal protein-restricted diet only during the first two of the three weeks of the lactation period). In addition, if a high-fat diet is given after weaning to these programmed rats, larger fat stores are observed (JC de Oliveira, LF Barella, RA Miranda and PCF Mathias, unpublished results). It is remarkable that the adult offspring of dams that were subjected to a protein-restricted diet during lactation have a high longevity even when fed an obesogenic diet ${ }^{(47)}$.

Apart from cholinergic stimulation, it is known that several other physiological signalling pathways are involved in the insulin secretion process in pancreatic islets. Either directly or indirectly, many other stimuli to $\beta$-cells are associated with the cholinergic signal, such as incretins ${ }^{(23,48)}$. It is important to keep in mind that many signalling pathways that increase or decrease glucose-induced insulin secretion exert their actions at the same time. Our laboratory has shown that adult rats that are protein malnourished during lactation exhibit an impaired ANS function with low vagal activity ${ }^{(18,19)}$, which can be the cause for changes in the MAChR subfamily composition. However, we cannot disregard the possibility that an imbalanced ANS is just an expression of the metabolic impairment observed in these programmed rats. Whether it is the cause or the effect, the ANS might play an important role in $\beta$-cell dysfunction caused by early protein restriction.
It is important to highlight that maternal milk production is reduced throughout lactation when lactating rat dams are fed a low-protein (8 or $10 \%$ ) diet, in which a low milk protein concentration $^{(49)}$ opposed to high milk leptin concentration as well as pups' serum leptin concentrations can be observed $^{(50)}$. During the suckling phase, leptin acts as a developmental promoter signal, mostly modulating hypothalamus neuronal cells and neurotransmitter connections ${ }^{(51)}$. Taken together, changes in leptin and amino acid content in rat dams' milk are indicative of organ and tissue developmental disturbances in offspring. As has been reported previously, the concentration of the transcription factor (pancreatic and duodenal homeobox 1) indispensable to pancreas as well as $\beta$-cell genesis, proliferation and maintenance is reduced by maternal protein restriction during gestation and lactation ${ }^{(52)}$. In agreement with this evidence, out data suggest that a weak milk composition of LP lactating dams could greatly modulate their pancreatic islet $\mathrm{mAChR}$ composition, inducing the islets to secrete low levels of insulin leading to the lean phenotype. However, the question as to which is the exact mechanism behind this process remains unsolved yet.

Maternal nutrition and low birth weight are recognised as crucial for the induction of late metabolic alterations, which have potential clinical importance and highlight the necessity for public policies to improve maternal and infant nutritional conditions, especially during pregnancy and/or lactation. It should be, nowadays, one of the major calls in developing countries globally. Currently, considering the high prevalence of metabolic diseases, such as type 2 diabetes, it is important to explore new therapeutics that target $\beta$-cell mAChR composition to treat or prevent metabolic diseases.

\section{Acknowledgements}

The present study was supported by the Brazilian Federal Foundation, Conselho Nacional de Desenvolvimento Científico e Tecnológico (CNPq) and Coordenação de Aperfeiçoamento de Pessoal de Nível Superior (CAPES), and the Parana Science Foundation (Fundação Araucária). The funders (CNPq, CAPES and Fundação Araucária) had no role in the design, analysis or writing of the manuscript. The contributions of the authors are as follows: P. C. F. M. and J. C. d. O. designed the study and revised the manuscript; J. C. d. O., R. A. M., L. F. B., A. R. A., T. A. S. R., C. C. S. F., A. M. and L. P. T. conducted the research; R. T., C. G. and J. C. d. O. analysed the data; J. C. d. O. and P. C. F. M. wrote the manuscript; P. C. F. M. acted as the principal investigator, provided support and reviewed the data and manuscript.

The authors declare that there is no conflict of interest associated with this manuscript.

\section{References}

1. Markakis EA (2002) Development of the neuroendocrine hypothalamus. Front Neuroendocrinol 23, 257-291.

2. Heijmans BT, Tobi EW, Stein AD, et al. (2008) Persistent epigenetic differences associated with prenatal exposure 
to famine in humans. Proc Natl Acad Sci U S A 105 17046-11749.

3. Sinclair KD, Allegrucci C, Singh R, et al. (2007) DNA methylation, insulin resistance, and blood pressure in offspring determined by maternal periconceptional $\mathrm{B}$ vitamin and methionine status. Proc Natl Acad Sci U S A 104, 19351-19356.

4. McMullen S \& Mostyn A (2009) Animal models for the study of the developmental origins of health and disease. Proc Nutr Soc 68, 306-320.

5. Hales CN \& Barker DJ (2001) The thrifty phenotype hypothesis. Br Med Bull 60, 5-20.

6. Barker DJ (2004) The developmental origins of chronic adult disease. Acta Paediatr Suppl 93, 26-33.

7. Reusens B \& Remacle C (2006) Programming of the endocrine pancreas by the early nutritional environment. Int J Biochem Cell Biol 38, 913-922.

8. Holness MJ, Langdown ML \& Sugden MC (2000) Early-life programming of susceptibility to dysregulation of glucose metabolism and the development of type 2 diabetes mellitus. Biochem J 349, 657-665.

9. Barbosa FB, Capito K, Kofod H, et al. (2002) Pancreatic islet insulin secretion and metabolism in adult rats malnourished during neonatal life. BrJ Nutr 87, 147-155.

10. James WP \& Coore HG (1970) Persistent impairment of insulin secretion and glucose tolerance after malnutrition. Am J Clin Nutr 23, 386-389.

11. Martin-Gronert MS \& Ozanne SE (2006) Maternal nutrition during pregnancy and health of the offspring. Biochem Soc Trans 34, 779-782.

12. Zambrano E, Bautista CJ, Deas M, et al. (2006) A low maternal protein diet during pregnancy and lactation has sex- and window of exposure-specific effects on offspring growth and food intake, glucose metabolism and serum leptin in the rat. $J$ Physiol 571, 221-230.

13. Fernandez-Twinn DS, Wayman A, Ekizoglou S, et al. (2005) Maternal protein restriction leads to hyperinsulinemia and reduced insulin-signaling protein expression in 21-mo-old female rat offspring. Am J Physiol Regul Integr Comp Physiol 288, R368-R373.

14. de Souza Caldeira Filho J \& Moura AS (2000) Undernutrition during early lactation period induces metabolic imprinting leading to glucose homeostasis alteration in aged rats. Res Commun Mol Pathol Pharmacol 108, 213-226.

15. Morimoto S, Calzada L, Sosa TC, et al. (2011) Emergence of ageing-related changes in insulin secretion by pancreatic islets of male rat offspring of mothers fed a low-protein diet. Br J Nutr 9, 1-4.

16. Ahren B (2000) Autonomic regulation of islet hormone secretion - implications for health and disease. Diabetologia 43, 393-410.

17. Gilon P \& Henquin JC (2001) Mechanisms and physiological significance of the cholinergic control of pancreatic beta-cell function. Endocr Rev 22, 565-604.

18. de Oliveira JC, Scomparin DX, Andreazzi AE, et al. (2011) Metabolic imprinting by maternal protein malnourishment impairs vagal activity in adult rats. $J$ Neuroendocrinol $\mathbf{2 3}$, $148-157$.

19. Gravena C, Andreazzi AE, Mecabo FT, et al. (2007) Protein restriction during lactation alters the autonomic nervous system control on glucose-induced insulin secretion in adult rats. Nutr Neurosci 10, 79-87.

20. Leon-Quinto T, Magnan C \& Portha B (1998) Altered activity of the autonomous nervous system as a determinant of the impaired beta-cell secretory response after protein-energy restriction in the rat. Endocrinology 139, 3382-3389.
21. Renuka TR, Robinson R \& Paulose CS (2006) Increased insulin secretion by muscarinic $M_{1}$ and $M_{3}$ receptor function from rat pancreatic islets in vitro. Neurochem Res 31, $313-320$.

22. Winzell MS \& Ahren B (2007) G-protein-coupled receptors and islet function-implications for treatment of type 2 diabetes. Pharmacol Ther 116, 437-448.

23. Drucker DJ (2006) The biology of incretin hormones. Cell Metabolism 3, 153-165.

24. Gautam D, Duttaroy A, Cui $\mathrm{Y}$, et al. (2006) $\mathrm{M}_{1}-\mathrm{M}_{3}$ muscarinic acetylcholine receptor-deficient mice: novel phenotypes. J Mol Neurosci 30, 157-160.

25. Lopes Da Costa C, Sampaio De Freitas M \& Sanchez Moura A (2004) Insulin secretion and GLUT-2 expression in undernourished neonate rats. J Nutr Biochem 15, 236-241.

26. Barbosa FB, Medina AR, Balbo SL, et al. (1999) Low protein diets administered to lactating rats affect in a time-dependent manner the development of young. Res Commun Mol Pathol Pharmacol 106, 63-76.

27. Trinder P (1969) Determination of blood glucose using an oxidase-peroxidase system with a non-carcinogenic chromogen. J Clin Pathol 22, 158-161.

28. Scott AM, Atwater I \& Rojas E (1981) A method for the simultaneous measurement of insulin release and B cell membrane potential in single mouse islets of Langerhans. Diabetologia 21, 470-475.

29. Gravena C, Mathias PC \& Ashcroft SJ (2002) Acute effects of fatty acids on insulin secretion from rat and human islets of Langerhans. J Endocrinol 173, 73-80.

30. Laemmli UK (1970) Cleavage of structural proteins during the assembly of the head of bacteriophage T4. Nature $\mathbf{2 2 7}$, 680-685.

31. Iismaa TP, Kerr EA, Wilson JR, et al. (2000) Quantitative and functional characterization of muscarinic receptor subtypes in insulin-secreting cell lines and rat pancreatic islets. Diabetes 49, 392-398.

32. Ozanne SE, Wang CL, Coleman N, et al. (1996) Altered muscle insulin sensitivity in the male offspring of proteinmalnourished rats. Am J Physiol 271, E1128-E1134.

33. Garcia-Souza EP, Da Silva SV, Felix GB, et al. (2008) Maternal protein restriction during early lactation induces GLUT4 translocation and mTOR/AKT activation in adipocytes of adults rats. Am J Physiol Endocrinol Metab 295, E626-E636.

34. Latorraca MQ, Reis MA, Carneiro EM, et al. (1998) Protein deficiency and nutritional recovery modulate insulin secretion and the early steps of insulin action in rats. $J$ Nutr 128, 1643-1649.

35. Dong XY \& Tang SQ (2010) Insulin-induced gene: a new regulator in lipid metabolism. Peptides 31, 2145-2150.

36. Rodriguez-Trejo A, Ortiz-Lopez MG, Zambrano E, et al. (2012) Developmental programming of neonatal pancreatic beta-cells by a maternal low-protein diet in rats involves a switch from proliferation to differentiation. Am J Physiol Endocrinol Metab 302, E1431-E1439.

37. Gautam D, Han SJ, Hamdan FF, et al. (2006) A critical role for beta cell $\mathrm{M}_{3}$ muscarinic acetylcholine receptors in regulating insulin release and blood glucose homeostasis in vivo. Cell Metab 3, 449-461.

38. Gautam D, Ruiz de Azua I, Li JH, et al. (2010) Beneficial metabolic effects caused by persistent activation of betacell $\mathrm{M}_{3}$ muscarinic acetylcholine receptors in transgenic mice. Endocrinology 151, 5185-5194.

39. Yamada M, Miyakawa T, Duttaroy A, et al. (2001) Mice lacking the $\mathrm{M}_{3}$ muscarinic acetylcholine receptor are hypophagic and lean. Nature 410, 207-212. 
40. Gautam D, Gavrilova O, Jeon J, et al. (2006) Beneficial metabolic effects of $\mathrm{M}_{3}$ muscarinic acetylcholine receptor deficiency. Cell Metab 4, 363-375.

41. Wells JC (2007) The thrifty phenotype as an adaptive maternal effect. Biol Rev Camb Philos Soc 82, 143-172.

42. Huang JS, Lee TA \& Lu MC (2007) Prenatal programming of childhood overweight and obesity. Matern Child Health J 11, 461-473.

43. Ravelli AC, van Der Meulen JH, Osmond C, et al. (1999) Obesity at the age of $50 \mathrm{y}$ in men and women exposed to famine prenatally. Am J Clin Nutr 70, 811-816.

44. Erhuma A, Bellinger L, Langley-Evans SC, et al. (2007) Prenatal exposure to undernutrition and programming of responses to high-fat feeding in the rat. BrJ Nutr $\mathbf{9 8}, 517-524$.

45. Orozco-Solis R, Lopes de Souza S, Barbosa Matos RJ, et al. (2009) Perinatal undernutrition-induced obesity is independent of the developmental programming of feeding. Physiol Behav 96, 481-492.

46. Vickers MH, Gluckman PD, Coveny AH, et al. (2005) Neonatal leptin treatment reverses developmental programming. Endocrinology 146, 4211-4216.
47. Ozanne SE \& Hales CN (2004) Lifespan: catch-up growth and obesity in male mice. Nature 427, 411-412.

48. Ruiz de Azua I, Gautam D, Guettier JM, et al. (2011) Novel insights into the function of beta-cell $\mathrm{M}_{3}$ muscarinic acetylcholine receptors: therapeutic implications. Trends Endocrinol Metab 22, 74-80.

49. Passos MCF, Ramos CF \& Moura EG (2000) Short and long term effects of malnutrition in rats during lactation on the body weight of offspring. Nutr Res 20, 1603-1612.

50. Bautista CJ, Boeck L, Larrea F, et al. (2008) Effects of a maternal low protein isocaloric diet on milk leptin and progeny serum leptin concentration and appetitive behavior in the first 21 days of neonatal life in the rat. Pediatr Res $\mathbf{6 3}$, $358-363$.

51. Bouret SG \& Simerly RB (2004) Minireview: leptin and development of hypothalamic feeding circuits. Endocrinology 145, 2621-2626.

52. Arantes VC, Teixeira VP, Reis MA, et al. (2002) Expression of PDX-1 is reduced in pancreatic islets from pups of rat dams fed a low protein diet during gestation and lactation. $J$ Nutr 132, 3030-3035. 